\title{
Hepatocyte Nuclear Factor 1-Alpha
}

National Cancer Institute

\section{Source}

National Cancer Institute. Hepatocyte Nuclear Factor 1-Alpha. NCI Thesaurus. Code C97827.

Hepatocyte nuclear factor 1-alpha (631 aa, $\sim 67 \mathrm{kDa}$ ) is encoded by the human HNF1A gene. This protein plays a role in transcriptional regulation. 